\title{
MORFOLOGI PROFIL TANAH VERTISOL DI KECAMATAN KRA- TON, KABUPATEN PASURUAN
}

\author{
Dwiyono Hari Utomo ${ }^{1}$
}

Email: dwiyono.hari.fis@um.ac.id

\begin{abstract}
Abstrak: Tanah vertisol mempunyai sifat mengembang dan mengkerut. Pada saat musim kemarau tanah retak bahkan pecah, tetapi pada saat musim penghujan tanah mengembang dan menggelombang. Sifat kembang kerut ini dipengaruhi oleh pembasahan dan pengeringan, terutama iklim yang tegas antara musim kemarau dan penghujan. Pada saat tanah retak dan pecah, materi tanah permukaan dapat mengisi masuk ke dalam retakan. Pada saat musim penghujan retakan terisi oleh larutan dan kemudian menutup rapat, bahkan mengembang. Perilaku liat yang demikian menyebabkan kekacauan horison. Penelitian ini ditujukan untuk mengetahui sifat-sifat tanah melalui morfologi profilnya. Profil tanah dibuat dengan ukuran $1 \times 1 \times 1-2$ meter sebanyak 4 profil pada elevasi yang berbeda. Setiap profil diambil sampel pada kedalaman $30 \mathrm{~cm}, 60 \mathrm{~cm}$, dan $90 \mathrm{~cm}$ dengan 4 kali ulangan, sehingga jumlah sampel 4 × 3 x $4=48$ sampel. Hasil penelitian menunjukkan struktur gumpal pada setiap kedalaman, tanah sulit diolah karena keras bila kering dan lengket bila basah. Berat jenis antara 2,41$2,81 \mathrm{~g} / \mathrm{cm}^{3}$, berat volume antara $1,01-1,21 \mathrm{~g} / \mathrm{cm}^{3}$, porositas antara 54,39 $61,25 \%$, dan konsistensi sangat teguh. Warna tanah didominasi warna hitam dengan gradasinya, yaitu 10YR 2/1 (black) dan 10YR 2/2 (very dark brown). Hitam kelam (10 YR 2/1) di horison permukaan dan hitam kecoklatan (10 YR 2/2) di horison sub permukaan. Perubahan warna dapat terjadi karena bahan organik yang lebih banyak di horison permukaan, sedangkan semakin dalam banyak mengandung kapur. Tumbuhan penutup tanah berupa rumput liar, atau tanpa tanaman budidaya. Secara umum dapat disimpulkan bahwa tanah ini memiliki sifat-sifat fisik yang jelek untuk budidaya pertanian.
\end{abstract}

Kata kunci: profil, vertisol, kraton

\section{PENDAHULUAN}

Tanah vertisol merupakan salah satu ordo dalam taksonomi tanah yang mengembang apabila dikenai air, mengkerut dan keras apabila kering. Sifat unik vertisols terkait dengan kembang kerut, sehingga terjadi pencampuran vertikal (pedoturbation), geser lateral, dan pembentukan retak, slickensides dan gilgai (Kovda, et al. 2010). Pada berbagai penggunaan tanah vertisol mengalami permasahan pada sifat kembang kerut, sebagai akibat perilaku liat montmorilonit. Vertisol didominasi oleh fraksi liat montmorilonit yang tersebar merata pada setiap horizon (A, AC, C) (Rafi'i, 1985). Sifat kembang kerut yang tinggi pada tanah vertisol selain bermasalah dalam hal pengelolaan, juga dapat menyebabkan bangunan rumah yang ada di atasnya cepat mengalami keretakan.

Sifat kembang kerut tanah vertisol yang menjadikan permukaan tanah berge- 
lombang, retak, pecah, dan terbelah, merupakan fenomena pedologis yang khas. Tanah vertisol yang dimanfaatkan sebagai lahan pertanian, maka faktor pembatas terletak pada ketersediaan air. Walaupun ketersediaan air yang cukup menjadikan tanah mengembang, tetapi mudah diolah, dibajak atau dipacul. Pada kondisi kering, tanah vertisol padat, pejal, keras, dan retak-retak, sulit diolah. Tanaman pada kondisi kering, akan layu dan mati, karena tanah mengambil cairan dalam tubuh tanaman.

Tanah vertisol memiliki sifat fisika, kimia, dan biologi yang berbeda setiap horizon utama dalam profilnya. Pembentukan tanah vertisol dipengaruhi oleh faktor pembentuk tanah seperti bahan induk, iklim, topografi, organisme, dan waktu. Tetapi pada penelitian ini perhatian utama pada faktor topografi atau toposekuen. Pada topografi yang bervariasi mengalami proses erosi, sedimentasi, dan fluvial yang menghasilkan bentuklahan yang bervariasi. Dengan demikian, morfologi profil tanah vertisol memiliki variasi sifat fisika, kimia, dan biologi pada setiap bentuk lahannya, maka perlu untuk dikaji morfologi profil pada variasi bentuk lahannya.

\section{Morfologi Profil Tanah Vertisol}

Klasifikasi tanah yang disusun oleh USDA dalam soil taxonomy, vertisol sebagai salah satu ordo tanah. Vertisol berasal dari bahasa latin verto yang artinya terbalik, yang terbalik adalah horisonnya, yaitu epipedon berada di subepipedon. Peristiwa ini terjadi karena adanya peretakan tanah pada saat kering, retakan dapat melampau horison A (epipedon) dan bagian tanah yang ada di permukaan masuk terperosok ke dalam retakan. Peristiwa tersebut menjadikan horison subepipedon terisi partikel tanah yang berasal dari horison epipedon, kondisi ini mengkacaukan horison, bahkan terjadi proses pedoturbasi. Pada penggunaan lahan pertanian dengan tanaman semusim horison epipedon kaya dengan bahan organik yang terlapuk ataupun yang belum terlapuk pasca panen. Bahan organik ini kemudian ditemukan di horison subepipedon yang menunjukkan adanya pembalikan horison.

Vertisol memiliki lapisan solum tanah yang agak dalam atau tebal yaitu antara 100-200 cm, berwarna kelabu sampai hitam, sedang teksturnya lempung berliat sampai liat. Kandungan liat tanah vertisol ini mencapai $>30 \%$ pada seluruh horizon, dengan sifat mengembang dan mengkerut. Pada keadaan kering tanah mengkerut menjadi pecah-pecah dan sebaliknya saat basah tanah mengembang dan lengket. Ritme ini terjadi pada wilayah yang mempunyai musim kemarau dan musim penghujan secara tegas. Retakan-retakan tanahnya pada saat kering ini lebarnya dapat mencapai $25 \mathrm{~cm}$ dan dalamnya dapat mencapai $60 \mathrm{~cm}$, keras berbongkah-bongkah. Vertisol mempunyai kemampuan meremah sendiri (self churning), adanya timbulan mikro gilgai, cermin sesar, dan struktur tanah berbentuk baji berukuran sangat kasar ( $\mathrm{Su}-$ tanto, 2015), dan ditemukan slickenside (Kovda, et al. 2010). Gilgai merupakan mikrotopografi dan disebut juga "crabhole," (Buol, et al. 2011). Vertisol mengandung 30-90\% liat (Legros, 2012), liat montmorilonit (aluminous,slightly magnesian clay minerals) atau $(\mathrm{OH})_{4} \mathrm{Si}_{3}\left(\mathrm{Al}_{3,34} \mathrm{Mg}_{66}\right) \mathrm{O}_{20} \quad$ yang 
122

Dwiyono Hari Utomo. Morfologi Profil Tanah Vertisol Di Kecamatan Kraton, Kabupaten

Pasuruan

memiliki perbandingan lembaran tetrahedral dengan octahedral 2:1 (Foth, 1978, Legros, 2012).

Bahan induk vertisol berupa sedimen yang didominasi liat smektit, atau hasil pelapukan batuan yang mengandung smektit. Sebaran terutama di daerah tropis, semi arid-sub humid dan daerah iklim mediterania yang berbeda antara musim kering dan basah (Driessen, et al. 2001; Kutilek, et al. 2010). Vertisol berbahan induk basalt di Australia, calcareous di West India, gneisses dan sandstones di India, deltaic deposits di USA, lacustrine deposits di Trinidad, glacio-lacustrine di Saskatchewan, marine deposits di Guyana, dan marl (Dengiz, et al. 2012). Tanah vertisol di Indonesia berkembang pada bahan induk yang berasal dari batuan vulkanik menengah yang kaya $\mathrm{Ca}$ plagioklas, tuff, batuan fesies laut, alluivium, dan colluvium dan bahan induk tanah yang merupakan hasil pelapukan dari batuan gampingan (Sartohadi, dkk. 2012). Suhu rata-rata tahunan $24-30^{\circ} \mathrm{C}$, suhu tertinggi $36-42^{\circ} \mathrm{C}$. Curah hujan tahunan antara $500-600 \mathrm{~mm}$ pada musim kering, 600-800 $(<1000)$ mm pada semiarid, dan 1000-1500 mm pada sub-humid (Murthy, et al. 1985).

Vertisol mempunyai variasi warna matrik yang cukup lebar, Hue berkisar antara 2,5Y hingga 10YR, value antara 26 dan chroma berkisar antara 0-4 (Prasetyo, 2007). Brownish-black (10YR 3/22/2), dark-reddish-brown (5YR 3/3), grayish-yellow-brown (10YR 4/2), dan dark-brown (7,5YR 3/3) (Özsoy, 2007). Pedoturbasi dan churning sebagai faktor utama morfologi vertisol. Agregat tanah permukaan lebih gelap dibandingan dengan bawah permukaan (Kovda, et al. 2010)

Vertisol secara luas terbentuk pada bentangan topografi yang lebih rendah (depresi) atau undulasi (Driessen, et al. 2001; Dengiz, et al. 2012) dengan iklim yang tegas antara basah dan kering. Musim kering yang panjang dimana evapotranspirasi potensial melebihi presipitasi menyebabkan rekahan semakin melebar. Pada saat musim hujan mulsa yang berada di permukaan masuk ke rekahan bersama material yang terlarut, meningkatkan pencucian garam dan karbonat, serta menurunkan kapasitas tukar sodium (Kutilek, et al. 2010). Iklim dan sifat tanah menjadi faktor pembatas vegetasi, biasanya tumbuh rumputrumputan sebagai vegetasi alami atau savana (Kutilek, et al. 2010; Driessen, et al. 2001).

Hasil proses pembentukan tanah dicerminkan dalam morfologi profil tanah yang bersangkutan. Morfologi tanah adalah corak, sifat dan karakteristik profil tanah. Profil tanah adalah penampang tegak tanah yang dibuat sedalam $\pm 1,5 \mathrm{~m}$ atau sampai bahan induk. Semua corak, sifat dan karakteristik yang harus diamati dari profil tanah adalah meliputi sifat fisik, kimia, dan biologi dan sifat-sifat lain seperti padas, air tanah, glei, bahan organik, keadaan batuan dan kerikil. Pembentukan lapisan atau perkembangan horizon dapat membangun tubuh alam yang disebut tanah. Tiap tanah dicirikan oleh susunan tertentu horizon. Secara umum dapat disebutkan bahwa setiap profil tanah terdiri atas dua atau lebih horizon utama.Tiap horizon dapat dibedakan berdasarkan warna, tekstur, struktur dan sifat mor-fologis lainnya. 


\section{METODE}

Penelitian ini merupakan penelitian deskriptif dengan menggunakan metode survey. Tujuannya untuk mendeskripsikan sifat fisika, kimia, dan biologi tanah pada setiap profil vertisol pada variasi ketinggian tempat. Variasi ketinggian tempat terjadi di masa sekarang, mewakili fungsi topografi masa lalu, karena proses pembentukan tanah telah terjadi di masa lalu sampai sekarang. Pada setiap variasi ketinggian ditentukan titik lokasi penentuan profil tanah. Profil tanah dipilih pada lahan tanpa vegetasi atau bero (mengurangi pengaruh akar). Sampel tanah diambil secara purposive sampling pada setiap horison profil tanah.

Objek penelitian diperoleh dari Peta Tanah Tinjau Provinsi Jatim skala 1: 250.000 (Lembaga Penelitian Tanah 1966), yaitu pada jenis tanah Grumusol Hitam (LPT) atau Vertisol (USDA). Lokasi penelitian pada vertisol di desa Gerungan, Kecamatan Kraton. Sampel titik ditentukan berdasarkan ketinggian tempat pada lahan kosong tanpa vegetasi dengan bantuan Google Earth, GPS, dan hasil observasi. Pada sampel titik yang sudah ditentukan dibuat profil tanah ukuran $1 \mathrm{x}$ $1 \mathrm{x}$ 1,5 m yang menunjukkan horison utama tanah. Pengambilan sampel tanah dilakukan menggunakan ring sampel tanah (cooper ring) pada horison yang terdeteksi. Melakukan uji laboratorium sifat sifat fisika, kimia, dan biologi tanah untuk menentukan sifat horison utama. Sifat horison utama terdiri dari: tekstur, struktur, porositas, permeabilitas, kandungan bahan organik, kapur $\left(\mathrm{CaCO}_{3}\right)$, dan $\mathrm{pH}$.. Menganalisis dan membahas hasil penelitian .

\section{HASIL PENELITIAN}

Secara umum pada setiap kedalaman sampel pada profil tanah mempunyai sifat fisika yang sama, yaitu tekstur liat, struktur blocky, warna hitam (10YR 2/1, black), konsistensi (kering) sangat teguh, sangat lekat bila lembap-basah, $\mathrm{pH}$, kandungan kapur, dan bahan organik. BJ, $\mathrm{BV}$, porositas, bervariasi pada berbagai kedalaman, selengkapnya lihat Tabel 4.1.

Tabel 4.1 Sifat Tanah Pada Setiap Profil

\begin{tabular}{|c|c|c|c|c|c|c|c|c|c|c|}
\hline Sampel & Tekstur & Struktur & Warna & $\mathrm{BJ}$ & $\mathrm{BV}$ & $\begin{array}{l}\text { Porosi } \\
\text { tas }\end{array}$ & $\begin{array}{l}\text { Kon- } \\
\text { sistensi }\end{array}$ & $\mathrm{pH}$ & Kapur & $\begin{array}{l}\text { Or- } \\
\text { ganik }\end{array}$ \\
\hline \multicolumn{11}{|l|}{$30 \mathrm{~cm}$} \\
\hline $1-3 \mathrm{~A}$ & liat & blocky & hitam & 2.51 & 1.08 & 56.99 & st & 7 & bs & $\mathrm{bb}$ \\
\hline $1-3 B$ & liat & blocky & hitam & 2.85 & 1.12 & 60.5 & st & 7 & bs & $\mathrm{bb}$ \\
\hline $1-3 C$ & liat & blocky & hitam & 3.19 & 1.1 & 65.49 & st & 7 & bs & $\mathrm{bb}$ \\
\hline $1-3 D$ & liat & blocky & hitam & 2.72 & 1.03 & 62.03 & st & 7 & bs & $\mathrm{bb}$ \\
\hline $\begin{array}{l}\text { Rata- } \\
\text { rata }\end{array}$ & liat & blocky & hitam & 2.81 & 1.08 & 61.25 & st & 7 & bs & $\mathrm{bb}$ \\
\hline \multicolumn{11}{|l|}{$60 \mathrm{~cm}$} \\
\hline $1-2 \mathrm{~A}$ & liat & blocky & hitam & 2.31 & 1.12 & 51.54 & st & 7 & $\mathrm{bb}$ & $\mathrm{bb}$ \\
\hline $1-2 B$ & liat & blocky & hitam & 2.59 & 1.03 & 60 & st & 7 & $\mathrm{bb}$ & $\mathrm{bb}$ \\
\hline $1-2 C$ & liat & blocky & hitam & 2.43 & 1.13 & 53.33 & st & 7 & $\mathrm{bb}$ & $\mathrm{bb}$ \\
\hline
\end{tabular}


124

Dwiyono Hari Utomo. Morfologi Profil Tanah Vertisol Di Kecamatan Kraton, Kabupaten Pasuruan

\begin{tabular}{|c|c|c|c|c|c|c|c|c|c|c|}
\hline $1-2 \mathrm{D}$ & liat & blocky & hitam & 2.51 & 1.12 & 55.24 & st & 7 & $\mathrm{bb}$ & $\mathrm{bb}$ \\
\hline $\begin{array}{l}\text { Rata- } \\
\text { rata }\end{array}$ & liat & blocky & hitam & 2.46 & 1.1 & 55.02 & st & 7 & $\mathrm{bb}$ & $\mathrm{bb}$ \\
\hline \multicolumn{11}{|l|}{$90 \mathrm{~cm}$} \\
\hline $1-1 \mathrm{~A}$ & liat & blocky & hitam & 2.49 & 0.96 & 61.38 & st & 7 & $\mathrm{bb}$ & $\mathrm{bb}$ \\
\hline $1-1 B$ & liat & blocky & hitam & 2.3 & 0.99 & 57.13 & st & 7 & $\mathrm{bb}$ & $\mathrm{bb}$ \\
\hline $1-1 C$ & liat & blocky & hitam & 1.93 & 0.93 & 51.77 & st & 7 & $\mathrm{bb}$ & $\mathrm{bb}$ \\
\hline $1-1 D$ & liat & blocky & hitam & 2.94 & 1.16 & 60.54 & st & 7 & $\mathrm{bb}$ & $\mathrm{bb}$ \\
\hline $\begin{array}{l}\text { Rata- } \\
\text { rata }\end{array}$ & liat & blocky & hitam & 2.41 & 1.01 & 57.7 & st & 7 & $\mathrm{bb}$ & $\mathrm{bb}$ \\
\hline \multicolumn{11}{|l|}{$30 \mathrm{~cm}$} \\
\hline $2-3 \mathrm{~A}$ & liat & blocky & hitam & 2.65 & 1.23 & 53.6 & st & 7 & $\mathrm{bb}$ & $\mathrm{bb}$ \\
\hline $2-3 B$ & liat & blocky & hitam & 2.48 & 1.07 & 56.82 & st & 7 & $\mathrm{bb}$ & $\mathrm{bb}$ \\
\hline $2-3 C$ & liat & blocky & hitam & 2.68 & 1.06 & 60.27 & st & 7 & $\mathrm{bb}$ & $\mathrm{bb}$ \\
\hline $2-3 D$ & liat & blocky & hitam & 2.56 & 1.11 & 56.82 & st & 7 & $\mathrm{bb}$ & $\mathrm{bb}$ \\
\hline $\begin{array}{l}\text { Rata- } \\
\text { rata }\end{array}$ & liat & blocky & hitam & 2.59 & 1.11 & 56.88 & st & 7 & $\mathrm{bb}$ & $\mathrm{bb}$ \\
\hline \multicolumn{11}{|l|}{$60 \mathrm{~cm}$} \\
\hline $2-2 \mathrm{~A}$ & liat & blocky & coklat & 2.77 & 1.17 & 57.68 & st & 7 & $\mathrm{bb}$ & $\mathrm{bb}$ \\
\hline $2-2 B$ & liat & blocky & coklat & 2.38 & 1.09 & 54.32 & st & 7 & $\mathrm{bb}$ & $\mathrm{bb}$ \\
\hline $2-2 C$ & liat & blocky & coklat & 2.61 & 1.08 & 58.67 & st & 7 & $\mathrm{bb}$ & $\mathrm{bb}$ \\
\hline $2-2 \mathrm{D}$ & liat & blocky & coklat & 2.57 & 1.15 & 55.19 & st & 7 & $\mathrm{bb}$ & $\mathrm{bb}$ \\
\hline $\begin{array}{l}\text { Rata- } \\
\text { rata }\end{array}$ & liat & blocky & coklat & 2.58 & 1.12 & 70.93 & st & 7 & $\mathrm{bb}$ & $\mathrm{bb}$ \\
\hline \multicolumn{11}{|l|}{$90 \mathrm{~cm}$} \\
\hline $2-1 \mathrm{~A}$ & liat & blocky & coklat & 2.76 & 1.07 & 61.14 & st & 7 & bs & $\mathrm{bb}$ \\
\hline $2-1 B$ & liat & blocky & coklat & 2.7 & 1.12 & 58.54 & st & 7 & bs & $\mathrm{bb}$ \\
\hline $2-1 C$ & liat & blocky & coklat & 2.59 & 1.12 & 56.82 & st & 7 & bs & $\mathrm{bb}$ \\
\hline $2-1 \mathrm{D}$ & liat & blocky & coklat & 2.48 & 1.07 & 56.82 & st & 7 & bs & $\mathrm{bb}$ \\
\hline $\begin{array}{l}\text { Rata- } \\
\text { rata }\end{array}$ & liat & blocky & coklat & 2.63 & 1.09 & 58.33 & st & 7 & bs & $\mathrm{bb}$ \\
\hline
\end{tabular}

Tabel lanjutan

\begin{tabular}{lllllllllll}
\hline Sampel & Tekstur & Struktur & Warna & BJ & BV & $\begin{array}{l}\text { Porosi- } \\
\text { tas }\end{array}$ & $\begin{array}{l}\text { Kon- } \\
\text { sistensi }\end{array}$ & pH & Kapur & $\begin{array}{l}\text { Or- } \\
\text { ganik }\end{array}$ \\
\hline 30 cm & & & & & & & & & & \\
3-2A & liat & blocky & hitam cokl & 2.75 & 1.28 & 53.33 & st & 7 & bs & bb \\
3-2B & liat & blocky & hitam cokl & 2.61 & 1.22 & 53.33 & st & 7 & bs & bb \\
3-2C & liat & blocky & hitam cokl & 2.58 & 1.09 & 57.58 & st & 7 & bs & bb \\
3-2D & liat & blocky & hitam cokl & 2.67 & 1.24 & 53.33 & st & 7 & bs & bb \\
\hline $\begin{array}{l}\text { Rata- } \\
\text { rata }\end{array}$ & liat & blocky & hitam cokl & 2.65 & 1.21 & 54.39 & st & 7 & bs & bb \\
\hline $\begin{array}{l}\text { 60 cm } \\
\text { 3-1A }\end{array}$ & liat & blocky & hitam cokl & 2.71 & 1.15 & 57.58 & st & 7 & bs & bb \\
3-1B & liat & blocky & hitam cokl & 2.75 & 1.28 & 53.33 & st & 7 & bs & bb
\end{tabular}




\begin{tabular}{|c|c|c|c|c|c|c|c|c|c|c|}
\hline $3-1 C$ & liat & blocky & hitam cokl & 2.73 & 1.16 & 57.58 & st & 7 & bs & $\mathrm{bb}$ \\
\hline $3-1 D$ & liat & blocky & hitam cokl & 2.41 & 1.13 & 53.33 & st & 7 & bs & $\mathrm{bb}$ \\
\hline $\begin{array}{l}\text { Rata- } \\
\text { rata }\end{array}$ & liat & blocky & hitam cokl & 2.65 & 1.18 & 55.45 & st & 7 & bs & $\mathrm{bb}$ \\
\hline \multicolumn{11}{|l|}{$30 \mathrm{~cm}$} \\
\hline $4-3 \mathrm{~A}$ & liat & blocky & hitam & 2.53 & 1.08 & 57.14 & st & 7 & bs & $\mathrm{bb}$ \\
\hline $4-3 B$ & liat & blocky & hitam & 2.77 & 1.34 & 51.67 & st & 7 & bs & $\mathrm{bb}$ \\
\hline $4-3 C$ & liat & blocky & hitam & 2.71 & 1.09 & 60 & st & 7 & bs & $\mathrm{bb}$ \\
\hline $4-3 \mathrm{D}$ & liat & blocky & hitam & 2.61 & 1.16 & 55.42 & st & 7 & bs & $\mathrm{bb}$ \\
\hline $\begin{array}{l}\text { Rata- } \\
\text { rata }\end{array}$ & liat & blocky & hitam & 2.65 & 1.17 & 55.3 & st & 7 & bs & $\mathrm{bb}$ \\
\hline $60 \mathrm{~cm}$ & & & & & & & & & bs & $\mathrm{bb}$ \\
\hline $4-2 \mathrm{~A}$ & liat & blocky & hitam & 2.55 & 0.95 & 62.55 & st & 7 & bs & $\mathrm{bb}$ \\
\hline $4-2 B$ & liat & blocky & hitam & 2.7 & 1.05 & 61.24 & st & 7 & bs & $\mathrm{bb}$ \\
\hline $4-2 C$ & liat & blocky & hitam & 2.72 & 1.01 & 62.98 & st & 7 & bs & $\mathrm{bb}$ \\
\hline $4-2 \mathrm{D}$ & liat & blocky & hitam & 2.41 & 1.14 & 52.93 & st & 7 & bs & $\mathrm{bb}$ \\
\hline $\begin{array}{l}\text { Rata- } \\
\text { rata }\end{array}$ & liat & blocky & hitam & 2.59 & 1.03 & 59.92 & st & 7 & bs & $\mathrm{bb}$ \\
\hline \multicolumn{11}{|l|}{$90 \mathrm{~cm}$} \\
\hline $4-1 \mathrm{~A}$ & liat & blocky & hitam & 2.33 & 1.02 & 56.11 & st & 7 & $\mathrm{sb}$ & $\mathrm{bb}$ \\
\hline $4-1 B$ & liat & blocky & hitam & 2.32 & 1.05 & 54.75 & st & 7 & $\mathrm{sb}$ & $\mathrm{bb}$ \\
\hline $4-1 C$ & liat & blocky & hitam & 2.61 & 1.09 & 58.35 & st & 7 & $\mathrm{sb}$ & $\mathrm{bb}$ \\
\hline 4-1D & liat & blocky & hitam & 2.42 & 1.04 & 56.86 & st & 7 & $\mathrm{sb}$ & $\mathrm{bb}$ \\
\hline $\begin{array}{l}\text { Rata- } \\
\text { rata }\end{array}$ & liat & blocky & hitam & 2.42 & 1.05 & 56.52 & st & 7 & $\mathrm{sb}$ & $\mathrm{bb}$ \\
\hline
\end{tabular}

Keterangan: $\mathrm{st}=$ sangat teguh, $\mathrm{bs}=$ berbuih sedikit, $\mathrm{bb}=$ berbuih banyak

\section{Gambar 4.1 Profil Tanah Vertisol}

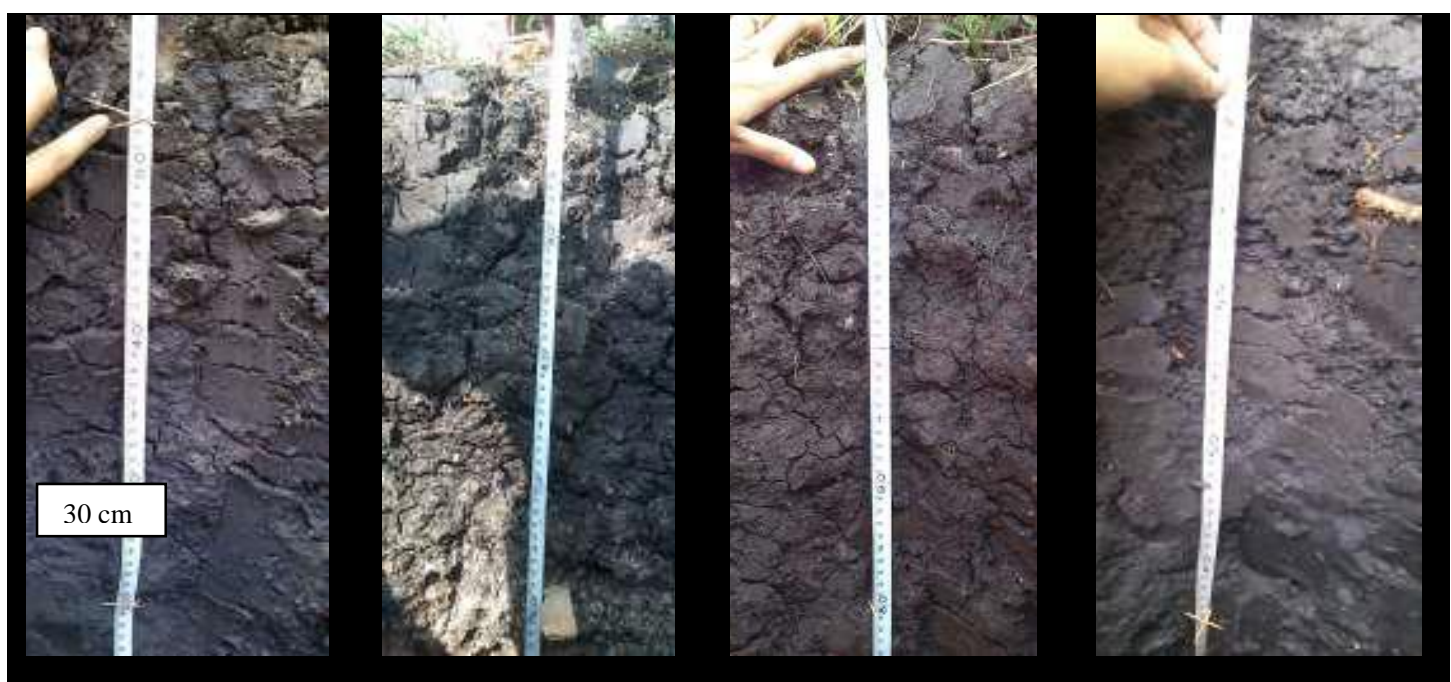




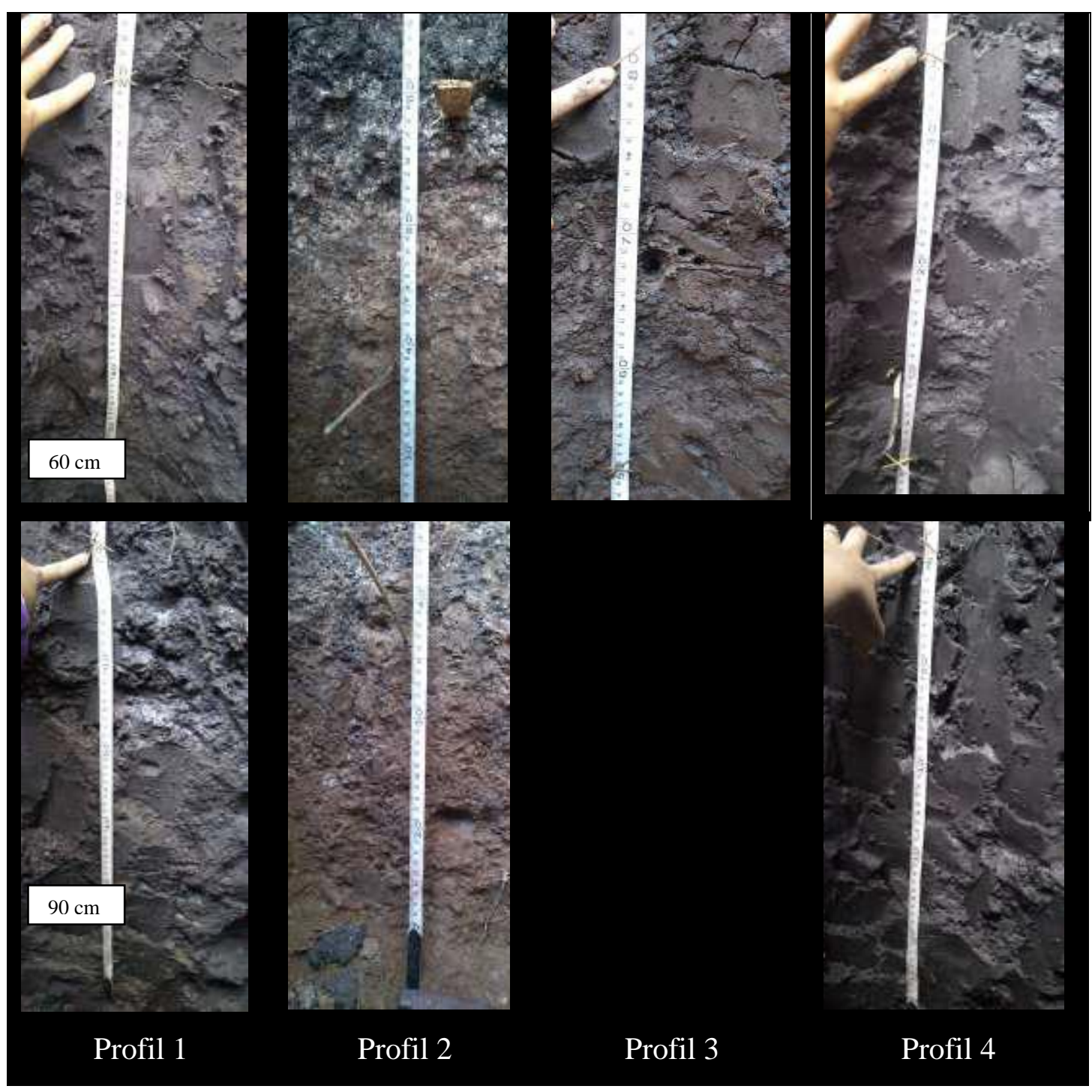

\section{PEMBAHASAN}

Profil tanah vertisol bervariasi kedalamannya sampai batas regolith, yaitu antara 100-200 cm. Pada kedalaman ini tidak tegas batas horisonnya,hal ini dapat terjadi karena tanah vertisol tidak memiliki horison eluviasi, sehingga tidak terbentuk horison illuviasi atau horison $\mathrm{B}$. Horison vertisol terusun daari horison $\mathrm{O}$ yang tipis diatas horison $\mathrm{A}$ dan $\mathrm{C}$ tanpa horison $\mathrm{B}$ atau disebut horison $\mathrm{A} / \mathrm{C}$. Topografi datar sampai bergelombang. Titik pengambilan profil tanah berdasar- kan elevasi, yaitu 4-7 mdpl. Variasi elevasi dimaksudkan untuk melihat proses erosi dan sedimentasi. Hasil pengamatan tidak ditemukan hasil erosi, hal ini menunjukkan bahwa wilayah Kecamatan Kraton relatif datar. Pada elevasi $7 \mathrm{mdpl}$ ketebalan profil $200 \mathrm{~cm}$, elevasi $6 \mathrm{mdpl}$ ketebalan profil $150 \mathrm{~cm}$, elevasi $5 \mathrm{mdpl}$ ketebalan profil $150 \mathrm{~cm}$, dan elevasi 4 mdpl ketebalan profil $100 \mathrm{~cm}$.

Vertisol dicirikan adanya pembalikan horison karena proses kembang kerut 
tanah. Horison permukaan (epipedon) ditemukan pada horison sub permukaan (sub epipedon) seperti bahan organik yang masih belum terlapuk sempurna ditemukan pada horison sub epipedon. Sifat kembang kerut tanah disebabkan pembasahan dan pengeringan pada mineral liat montmorilonit tipe 2:1. Tanah mengembang jika air mengisi seluruh ruang pori atau dalam kondisi jenuh, dan mengkerut jika tanah kering yang berkepanjangan. Sifat kembang kerut ini berlangsung sesuai dengan periode musiman, yaitu antara musin penghujan dan musim kemarau. Pada keadaan kering tanah mengkerut menjadi pecahpecah dan sebaliknya saat basah tanah mengembang dan lengket. Retakanretakan tanahnya pada saat kering ini lebarnya mencapai $15 \mathrm{~cm}$, dalamnya mencapai $50 \mathrm{~cm}$, keras, dan berbongkahbongkah.

Tiga mineral penting di daerah tropis yaitu gibbsite (formed in the complete absence of silica), kaolinite and montmorillonite (Duchaufour,1982). Montmorilonit sebagai contoh smektit yang mempunyai formula kimia (1/2 $\mathrm{Ca}, \mathrm{Na})(\mathrm{Al}, \mathrm{Mg}$, $\mathrm{Fe})_{4}\left(\mathrm{Si}, \quad \mathrm{Al}_{8} \mathrm{O}_{20}(\mathrm{OH})_{4} \cdot \mathrm{nH}_{2} \mathrm{O}\right.$. Smektit merupakan liat yang memiliki struktur TO-T, satu liat Alumina Oktahedral diapit oleh dua liat Silika Tetrahedral. Terdapat sejumlah $\mathrm{Mg}$ dan Fe yang tersubstitusi ke dalam lapisan oktahedral. $\mathrm{H}_{2} \mathrm{O}$ dapat terabsorbsi ke dalam lembaran T-O-T sehingga mengembang, oleh sebab itu smektit dikenal sebagai expanding clay.

Berdasarkan sifat kembang kerut vertisol, maka tekstur vertisol didominasi oleh partikel liat. Hal ini dapat terjadi karena hanya liat yang mampu melakukan kembang kerut. Sifat liat di lapangan menunjukkan tanah dapat digulung dalam ukuran 1-2 mm tanpa putus, pada kondisi lembap, dan dalam kondisi lembap-basah tanah sangat lekat. Keberadaan tekstur liat terkait dengan berat jenis, berat volume, porositas, konsistensi, dan kemampuan kembang kerut. Kandungan liat semakin dalam semakin tinggi.

Berat jenis antara $2,41-2,81 \mathrm{~g} / \mathrm{cm}^{3}$, berat volume antara $1,01-1,21 \mathrm{~g} / \mathrm{cm}^{3}$, porositas antara 54,39-61,25\%, dan konsistensi sangat teguh. Berat jenis semakin besar maka semakin kecil kemampuan mengembang (swelling), sebaliknya berat jenis semakin kecil maka semakin besar kemampuan mengembang (swelling). Pengembangan terjadi pada kandungan air yang banyak, sedangkan kandungan air sedikit, tanah menyusut bahkan retak, pecah, dan mengeras. (Taboada, 2003).

Tanah yang bertekstur halus mempunyai berat jenis yang lebih kecil dibandingkan dengan tanah yang bertekstur kasar. Hal ini disebabkan oleh total ruang pori yang lebih banyak pada tekstur liat dibandingkan dengan pasir, sehingga porositas liat lebih besar dibandingkan dengan porositas pasir. Nilai porositas yang besar menunjukkan ruang total pori yang banyak dibandingkan dengan volume padatannya. Semakin halus teksturnya semakin besar porositasnya, sehingga tekstur dan porositas merupakan hubungan terbalik.

Fase kembang kerut dimulai dari retakan kecil sewaktu musim kemarau, dan terus megalami peretakan yang semakin melebar dan dalam. Pada musim hujan, retakan terisi oleh air hujan bersama material terlarut atau material lain yang ada di permukaan. Retakan tertutup, karena tanah mengembang, menghasilkan gun- 
128

Dwiyono Hari Utomo. Morfologi Profil Tanah Vertisol Di Kecamatan Kraton, Kabupaten Pasuruan

dukan atau penggelombangan pada permukaan tanah. Musim hujan seterusnya melakukan erosi permukaan (Duchaufour,1982)

Struktur tanah vertisol gumpal (blocky) pada seluruh profil, dengan konsistensi teguh atau keras kalau kering. Sifat kembang kerut ini menjadikan vertisol mempunyai kemampuan meremah sendiri (self churning) menunjukkan struktur baji, sebagaimana dinyatakan oleh Kutilek and Nielsen (2001). Bahan induk vertisol di Kraton, Pasuruan berdasarkan peta bahan induk Badan Pertanahan Nasional Kabupaten Pasuruan tahun 2004 adalah endapan liat dan tuf vulkan. Montmorilonit merupakan komponen utama bentonit yang terbentuk sebagai akibat pelapukan tuf vulkan (Chitraningrum, 2008).

Warna tanah didominasi warna hitam dengan gradasinya, yaitu 10YR 2/1 (black) dan 10YR 2/2 (very dark brown). Hitam kelam (10 YR 2/1) di horison permukaan dan hitam kecoklatan (10 YR 2/2) di horison sub permukaan. Perubahan warna dapat terjadi karena bahan organik yang lebih banyak di horison permukaan, sedangkan semakin dalam banyak mengandung kapur. Kandungan bahan organik lapisan tanah atas cukup tinggi karena penutup tanah berupa hamparan rumput liar dan sisa tanaman semusim (jagung). Kandungan bahan organik tanah dilakukan dengan cara kualitatif, yatu dengan meneteskan larutan $\mathrm{H}_{2} \mathrm{O}_{2} 10 \%$. Semakin ke bawah kandungan bahan organik semakin menurun, karena bahan organik tidak tercuci (eluviasi) kecuali dalam bentuk koloid humus. Temuan bahan organik pada kedalaman $30 \mathrm{~cm}$ menunjukkan bahwa tanah men- galami pembalikan horison (verto), karena bahan organik menyusup ketika tanah pecah.

Kandungan kapur ditentukan dengan cara kualitatif yaitu dengan menetesi $\mathrm{HCl}$ $10 \%$. Pada setiap kedalaman terdapat kapur yang ditandai buih ketika ditetesi $\mathrm{HCl}$ $10 \%$. Hal ini menunjukkan bahwa kapur merupakan material terlarut bersama air hujan, tetapi dapat juga terjadi karena sedimentasi. Sebagaimana pernyataan Duchaufour (1982) secara umum terjadi di plain (dataran), dan cekungan yang terisi oleh liat yang diperkaya kalsium dan magnesium, liat mengembang diperkaya silikat (montmorilonit). Daerah Gerongan, Kraton mempunyai kemiringan $2 \%$ (datar).

Reaksi tanah netral $(\mathrm{pH}=7,00)$. Hal ini selain kandungan kapur dan organik, tanah tidak mengalami penjenuhan atau penggenangan yang dapat menurunkan $\mathrm{pH}$ tanah, dan tidak ditemukan adanya bercak kemerahan sebagai akibat draenase yang jelek.

\section{KESIMPULAN}

Berdasarkan hasil penelitian dan pembahasan dapat disimpulkan bahwa:

1. Vertisol didominasi tekstur liat yang menyebabkan retak di musim kemarau dan mengembang di musim hujan. Retak dan mengembang menyebabkan perubahan volume yang menghasilkan permukaan tanah tidak rata atau bergelombang.

2. Struktur gumpal pada setiap kedalaman, hal ini terkait dengan dominasi liat, tanah sulit diolah karena keras bila kering dan lengket bila basah. 
3. Profil tanah terobservasi pada kedalaman 100-200 cm sampai pada batuan induk yang keras. Pada elevasi $7 \mathrm{mdpl}$ ketebalan profil $200 \mathrm{~cm}$, elevasi 6 mdpl ketebalan profil $150 \mathrm{~cm}$, elevasi 5 mdpl ketebalan profil $150 \mathrm{~cm}$, dan elevasi 4 mdpl ketebalan profil 100 $\mathrm{cm}$.

4. Warna tanah 10YR 2/1 (black) dan 10YR 2/2 (very dark brown).

5. Berat jenis antara $2,41-2,81 \mathrm{~g} / \mathrm{cm}^{3}$, berat volume antara $1,01-1,21 \mathrm{~g} / \mathrm{cm}^{3}$, porositas antara 54,39-61,25\%, dan konsistensi sangat teguh.

6. Bahan organik relatif tinggi dan kapur bervariasi.

7. Terobservasi tidak ditemukan flora dan fauna dalam tanah.

8. Tumbuhan penutup tanah berupa rumput liar, atau tanpa budidaya tanaman (bero), karena tanah kering, keras, dan retak-retak.

\section{DAFTAR RUJUKAN}

Buol, S.W., Southard, R.J., Graham, R.C., Mcdaniel, P.A. 2011. Soil Genesis And

Classification. Sixth Edition. Iowa: John Wiley \& Sons, Inc.

Chitraningrum, Nidya. 2008. Sifat Mekanik.(online),

(http://lib.ui.ac.id/file?file=digital/1 25332-FIS.014-08-

Sifat\%20mekanik-Literatur.pdf), diakses tanggal 24 Februari 2016.

Dengiz, Orhan; Sağlam, Mustafa; Sarioğlu, F. Esra; Saygin, Fikret; and Atasoy, Çağla. 2012. Morphological and Physico-Chemical Characteristics and Classification of Vertisol Developed on Deltaic Plain,(online), (http://file.scirp.org/pdf/OJSS20120 100003_96767584.pdf), diakses tanggal 3 Mei 2016.

Driessen, Paul; Deckers, Jozef; Nachtergaele, Freddy. 2001. Lecture Notes On The Major Soils Of The World. Rome: Food And Agriculture Organization Of The United Nations. (online), (ftp://ftp.fao.org/agl/agll/docs/wsrr9 4e.pdf), diakses 15 Februari 2016.

Duchaufour, P. 1982. Pedology, Pedogenesis and Classification. Sydney: George Allen \& Unwin

Foth, Henry D. 1978. Dasar-dasar Ilmu Tanah Edisi ke Enam. Terjemahan Soenartono Adisoemarto. 1994. Jakarta: Erlangga

Kovda, I., Morgun, E., and Boutton, T.W. 2010. Vertic Processes and Specificity of Organic Matter Properties and Distribution in Vertisols. ISSN 1064_2293, Eurasian Soil Science, 2010, Vol. 43, No. 13, pp. 14671476. (C) Pleiades Publishing, Ltd., 2010, (online),

(http://agrilifecdn.tamu.edu/boutton /files/2013/01/Verticsoilprocesses

Morgun2010_12.pdf.), diakses 24 Februari 2015.

Kutilek, M. and Nielsen, D.R. 2001. Hydrologic Processes in Vertisols. Elsevier

Soil and Tillage Research. Prague. Czech Republic.

LPTI. 1966. Peta Tanah Tinjau Provinsi Jatim skala 1: 250.000.

Legros, Jean-Paul. 2012. Major Soil Groups of the World Ecology, Genesis, Properties and Classification. CRC Press: New York.

Murthy, R.S.; Bhattacharjee, J.C.; Landey, R.J.; And Pofali, R.M. 1982. Distribution, Characteristics And Classification of Vertisols. 12th International Congress Of Soil Science New Delhi, India 8-16 February1982,(online), 
130

Dwiyono Hari Utomo. Morfologi Profil Tanah Vertisol Di Kecamatan Kraton, Kabupaten

Pasuruan

(http://iuss.org/19th\%20WCSS/Sy mposium/pdf/2035.pdf), diakses 26 Februari 2016.

Özsoy, Gökhan, and Aksoy, Ertuğrul. 2007. Characterization, classification and agricultural usage of vertisols developed on neogen aged calcareous marl parent materials, (online),

(http://jbes.uludag.edu.tr/PDFDOS YALAR/mak-2.pdf), diakses tanggal 15 Februari 2016.

Prasetyo, B.H. 2007. Perbedaan SifatSifat Tanah Vertisol dari Berbagai Bahan Induk. Jurnal Ilmu-Ilmu Pertanian Indonesia. Volume 9, No. 1, 2007, Hlm. 20 - 31, (online), (repository.unib.ac.id/19/1/20JIPI- 2007.pdf.), diakses tanggal 27 November 2014.

Rafi'i, Suryatna. 1985. Ilmu Tanah. Bandung: Angkasa

Sartohadi, Junun, dan Jamulya, dan Dewi, Nur Indah Sari. 2012. Pengantar Geografi Tanah. Yogyakarta: Pustaka Belajar

Sutanto, Rachman. 2005. Dasar-dasar ilmu Tanah. Yogyakarta: Kanisius

Taboada, Miguel A. 2003. Soil Shrinkage Characteristics in Swelling Soils, (online),

(www.ictp.it/ pub_off/lectures/.../3 9Taboada1.pdf), diakses tanggal 15 Februari 2016

USDA. 2002. Soil Taxonomy 